\title{
Lysophosphatidic acid-triggered pathways promote the acquisition of trophoblast endovascular phenotype in vitro
}

\author{
Jimena S. Beltrame ${ }^{1}$ (D) | Micaela S. Sordelli ${ }^{1} \mid$ Vanesa A. Cañumil $^{1}$ \\ Ana M. Franchi ${ }^{2}$ | María L. Ribeiro ${ }^{1}$
}

${ }^{1}$ Laboratory of Physiology and Pharmacology of Reproduction, Centre for Pharmacological and Botanical Studies (CONICET - School of Medicine,

University of Buenos Aires), Buenos Aires, Argentina

${ }^{2}$ Laboratory of Physiopathology of Pregnancy and Labor, Centre for Pharmacological and Botanical Studies (CONICET - School of Medicine, University of Buenos Aires), Buenos Aires, Argentina

\section{Correspondence}

Jimena S. Beltrame, Laboratory of Physiology and Pharmacology of

Reproduction, Centre for Pharmacological and Botanical Studies (CONICET - School of Medicine, University of Buenos Aires), Paraguay 2155, 16th floor, CP (C1121ABG), Buenos Aires, Argentina Email: jimenabeltrame@gmail.com

\section{Funding information}

Fundación Alberto J. Roemmers, Grant number: M.S. Sordelli; Scientific and Technological Research Fund (FONCyT) $2013 \mathrm{~N}^{\circ}$ 0285; Fondo para la Investigación Científica y Tecnológica PIP $2015 \mathrm{~N}^{\circ} 0764$

\begin{abstract}
Successful implantation and placentation requires that extravillous cytotrophoblast acquires an endovascular phenotype and remodels uterine spiral arteries. Defects in this mechanism correlate with severe obstetric complications as implantation failure and preeclampsia. Lysophosphatidic acid (LPA) participates in embryo implantation and contributes to vascular physiology in different biological systems. However, the role of LPA on trophoblast endovascular transformation has not been studied. Due to difficulties in studying human pregnancy in vivo, we adopted a pharmacological approach in vitro to investigate LPA action in various aspects of trophoblast endovascular response, such as the formation of endothelial capillary-like structures, migration, and proliferation. The HTR-8/SVneo cell line established from human first trimester cytotrophoblast was used to model the acquisition of the endovascular phenotype by the invading trophoblast. LPA increased HTR-8/SVneo tube formation, migration (wound healing assay and phalloidin staining) and proliferation (MTT assay). LPA G protein-coupled receptors, $\mathrm{LPA}_{1}$ and $\mathrm{LPA}_{3}$, were expressed in HTR-8/SVneo. By using selective antagonists, we showed that enhanced tubulogenesis was mediated by $\mathrm{LPA}_{3}$. In addition, cyclooxygenase- 2 and inducible nitric oxide synthase pathways participated in LPA-stimulated tubulogenesis. Inducible nitric oxide synthase was activated downstream cyclooxygenase-2. Furthermore, prostaglandin E2 and a nitric oxide donor (SNAP) increased trophoblast tube formation in a concentration-dependent manner. Finally, we observed that cyclooxygenase- 2 and inducible nitric oxide synthase were localized in the nucleus, and LPA did not modify their cellular distribution. Our results show that LPAtriggered regulatory pathways promote trophoblast endovascular response in vitro, suggesting a new role for LPA during spiral artery remodeling at the maternal-fetal interface.
\end{abstract}

\section{K E Y W O R D S}

cyclooxygenase-2, endovascular trophoblast, inducible nitric oxide synthase, $\mathrm{LPA}_{3}$ receptor, lysophosphatidic acid 


\section{1 | INTRODUCTION}

The establishment of successful pregnancy requires a profound reorganization of uterine and fetal tissues. The coordination of vascular processes at the maternal-fetal interface is crucial and involves extravillous trophoblast differentiation into endovascular trophoblast. Endovascular trophoblast invades maternal spiral arteries, and not only disrupts the endothelium-myometrium interactions, but also replaces endothelial and myometrial cells, while acquiring an endothelial-like phenotype. ${ }^{1}$ The adequate remodeling of the uterine vessels ensures sufficient blood flow in response to the increasing metabolic demands of the embryo. Failure to achieve these transformations is correlated with severe obstetric complications such as implantation failure and preeclampsia. ${ }^{2,3}$ Much effort is being made to elucidate the molecules and mechanisms that underlie the transformation of fetal trophoblast into the endovascular phenotype. Understanding the possible causes of the disorders associated with inadequate vascular remodeling would help to design new strategies to alleviate these pathologies.

Some of the most widely studied mediators of physiological responses in reproduction are the phosphorylated lipids such as LPA. LPA regulates several female reproductive functions through G-protein coupled receptors as $\mathrm{LPA}_{3}{ }^{4}$ Also, LPA modulates blood vessel development, and contributes to vascular pathology in different biological systems. ${ }^{5}$ Previously, we showed that LPA via $\mathrm{LPA}_{3}$ augments the expression of interleukin-10, a vascular marker, in the rat uterus during implantation. ${ }^{6}$ Moreover, we observed that blocking $\mathrm{LPA}_{3}$ in vivo modifies the development of uterine vessels with an outcome in the formation of the decidua and placenta, and compromising the growth of the embryos. ${ }^{7}$ As mentioned above, vessel remodeling at the sites of implantation involves the interplay between different cell types and mediators from the maternal and fetal components. In this sense, other authors showed that through LPA-induced chemokine production, human first-trimester trophoblast and endometrial stromal cells regulate in vitro angiogenesis of human endometrial microvascular endothelial cells. ${ }^{8,9}$ However, the effect of LPA on the acquisition of the endovascular phenotype in human cytotrophoblast cells remains unclear.

Besides LPA, cyclooxygenase (COX) and nitric oxide synthase (NOS) are two well-known enzymes involved in vascular processes during early gestation. Prostaglandin E2 and prostacyclin derived from cyclooxygenase-2 (COX-2) increase vascular permeability at the implantation sites in mice. ${ }^{10,11}$ Interestingly, $\mathrm{LPA}_{3}$ and COX-2 knock out mice show similar implantation defects, and the administration of prostaglandin E2 and prostacyclin to $\mathrm{LPA}_{3}{ }^{-/}$females rescues delayed implantation. ${ }^{4,12}$ NOS catalyzes the production of nitric oxide, and exists in three isoforms: endothelial
NOS, neuronal NOS, and inducible NOS (iNOS). We observed that NOS activity is increased at the sites of embryo implantation, and this regulation depends on the presence of the blastocyst. ${ }^{13}$ Deregulation of nitric oxide tone and NOS expression is related to reduced implantation rates due to vascularization defects in the rat uterus. ${ }^{14,15}$ Previously, we found that LPA augments COX-2 and iNOS during implantation in the rat uterus by activating $\mathrm{LPA}_{3}$ receptor, and these pathways are involved in LPA-stimulated interleukin-10 expression. ${ }^{6,16}$ Therefore, COX and NOS activated downstream LPA-LPA 3 seem to modulate vascular events during implantation in the rat.

Based on these antecedents, we hypothesize that LPA modulates endovascular extravillous trophoblast adaptations during spiral artery remodeling through the regulation of vascular mediators such as prostaglandins and nitric oxide. Therefore, our first objective was to investigate the action of LPA in trophoblast capillary-like tube formation, migration, and proliferation. Then, we studied if COX-2 and iNOS regulatory pathways are involved in the action of LPA on trophoblast tubulogenesis.

\section{2 | MATERIALS AND METHODS}

\section{1 | Cell culture}

The immortalized human first trimester trophoblast cell line HTR-8/SVneo (kind gift from Dr Udo Markert, Plancenta Lab, Department of Obstetrics, Jena University Hospital, Jena) was maintained as previously described. ${ }^{17}$ The HTR-8/ SVneo trophoblast cells were obtained from explant cultures of human first trimester placenta (8-10 weeks of gestation) and immortalized by transfection with a cDNA construct that encodes the SV40 large T antigen. ${ }^{17}$ These cells are nontumourigenic and metastatic, and although they are highly invasive in vitro, they are not tumorigenic when injected into nude mice. HTR-8/SVneo cells exhibit various properties of extravillous cytotrophoblasts including the expression of cytokeratins 7, 8, and 18, placental alkaline phosphatase, uPAR, human leukocyte antigen (HLA) framework antigen $\mathrm{W} 6 / 32$, IGF-II mRNA, and protein, as well as an integrin profile characteristic of invasive cytotrophoblasts. ${ }^{17,18}$ These cells have been shown to secrete variable levels of $\mathrm{hCG},{ }^{19}$ and to express cytoplasmic and membrane-associated HLAG. $^{20,21}$ This trophoblast cell line was used to model endovascular trophoblast behavior at the maternal-fetal interface. Cells were incubated in culture flasks at $37^{\circ} \mathrm{C}$ with $5 \% \mathrm{CO}_{2}$ in DMEM/F12 medium (Gibco, Invitrogen, Buenos Aires, Argentina) supplemented with $10 \%$ fetal bovine serum (Natocor, Córdoba, Argentina), $100 \mathrm{U} / \mathrm{mL}$ penicillin (Gibco, Invitrogen, Argentina), $100 \mu \mathrm{g} / \mathrm{mL}$ streptomycin (Gibco, Invitrogen, Argentina), and 1\% glutamine (MicroVet SRL, Lobov, Buenos Aires, Argentina). 


\subsection{Tube formation assay}

Tube formation assay was performed as previously described. $^{22}$ Briefly, 96-well plates were coated with $50 \mu \mathrm{L} /$ well of Geltrex ${ }^{\circledR}$ (Gibco, Invitrogen, Argentina) and incubated at $37^{\circ} \mathrm{C}$ for $30 \mathrm{~min}$ to promote solidification. HTR-8/SVneo cells $\left(15 \times 10^{3} /\right.$ well $)$ were seeded on the top of the gel and incubated at $37^{\circ} \mathrm{C}$ with $5 \% \mathrm{CO}_{2}$ in DMEM/F12 medium without fetal bovine serum. Cells were treated with LPA (1oleoyl-lysophosphatidic acid 18:0, Cayman Chemical, Migliore Laclaustra, Buenos Aires, Argentina), BMT (BMT183172-01-002, LPA 1 antagonist, Bristol Myers Squibb), DGPP (diacylglycerol pyrophosphate 8:0, LPA 3 antagonist, Sigma Aldrich Co., Argentina), BrP-LPA (1-bromo-3(S)hydroxy-4-(palmitoyloxy)-butyl-phosphonate, $\mathrm{LPA}_{1}$ to $\mathrm{LPA}_{4}$ antagonist, Echelon Biosciences, Inc., Pennsylvania), prostaglandin E2 (Sigma Aldrich Co., Argentina), SNAP (SNitroso-N-acetyl-DL-penicillamine, Sigma Aldrich Co., Argentina), DGPP (diacylglycerol pyrophosphate 8:0, Sigma Aldrich Co., Argentina), indomethacin (, Argentina), NS-398 (Cayman Chemical, Argentina), 1400W (Cayman Chemical, Migliore Laclaustra, Montpellier Argentina) and L-NAME (Sigma Aldrich Co., Argentina). After 6 or 24 h, tubules were observed in an inverted light microscope (10x, IMT2 Olympus) and photographed with a digital camera (Olympus C-5060). Five different fields per well were analyzed and extreme edges were excluded due to gel meniscus formation. Image $\mathbf{J}$ (open source) software package was used to quantify tubule length of the capillary network formation. The length of each tubule was determined by drawing a line over each tubule and the mean length of the lines (pixels) drawn in each image was calculated. The number of capillary connections or branch points between cells was counted manually.

\section{3 | RNA isolation and polymerase chain reaction analysis (PCR)}

Total RNA isolation, cDNA synthesis and real time PCR were performed as previously described. ${ }^{13,16}$ Briefly, total RNA was isolated using Tri Reagent according to the manufacturer's recommendations (Molecular Research Center, Genbiotech, Buenos Aires, Argentina). RNA was thawed on ice, quantified spectrophometrically at 260 and $280 \mathrm{~nm}$ and RNA quality assessed using GelRed ${ }^{\mathrm{TM}}$ nucleic acid stained gels. RNA with a 260:280 ratio of 1.8 and above was further treated with RNase free DNase I to digest contaminating genomic DNA. First strand cDNA was synthesized from total RNA $(3 \mu \mathrm{g})$ using Moloney murine leukemia virus reverse transcriptase (MMLV-RT) and random primers according to the manufacturer's recommendations (Invitrogen, Argentina) in the presence of ribonuclease inhibitor. The PCR conditions in all cases started with a denaturation step at $95^{\circ} \mathrm{C}$ for $30 \mathrm{seg}$ and followed by up to 30 cycles of denaturation, annealing, and primer extension (LPA 1 and $\left.\mathrm{LPA}_{3}: 94^{\circ} \mathrm{C} \quad 40 \mathrm{seg}, 59^{\circ} \mathrm{C} 30 \mathrm{seg}, 72^{\circ} \mathrm{C} 1 \mathrm{~min}\right)$. PCR primers are detailed for $\mathrm{LPA}_{1}$ (Forward $5^{\prime}$-TGTTAGCACATGGCTCCTTC-3', Reverse 5'-ATGACCACAATGACCACCAC-3') and LPA $_{3}$ (Forward 5'-CTTAGG GGCGTTTGTGGTAT-3', Reverse 5'-GTGCCATACATGTCCTCGTC- $3^{\prime}$ ). PCR products were resolved in $2 \%$ agarose gels and visualized by GelRed ${ }^{\mathrm{TM}}$ nucleic acid staining. Photographs were taken using a digital camera Olympus C-5060.

\subsection{Evaluation of actin filaments}

Actin filaments were evaluated as previously described with some modifications. ${ }^{23}$ HTR-8/SVneo cells were grown to confluence on glass coverslips and incubated with LPA $10 \mu \mathrm{M}$ for $6 \mathrm{~h}$. Actin staining with TRITC-phalloidin (Sigma Aldrich Co., Buenos Aires, Argentina) was performed following manufacturer recommended procedures. Cells were fixed in $3.7 \%$ formaldehyde solution in PBS for $10 \mathrm{~min}$, permeabilized with $0.1 \%$ TRITON X-100 in PBS for 5 min and stained with $50 \mu \mathrm{g} / \mathrm{mL}$ of TRITC-phalloidin in PBS for $40 \mathrm{~min}$ at room temperature. Then, cells were mounted on glass-slices using DABCO mounting medium (Sigma, Buenos Aires, Argentina) and observed by fluorescence microscopy at 100× (Nikon Eclipse 200, Buenos Aires, Argentina).

\subsection{Wound healing assay}

HTR-8/SVneo cells were plated at $10^{4}$ cells per well in a 24-well plate. When cells reached confluence, a wound was made with a sterile tip $(200 \mu \mathrm{L})$. The monolayer was washed to eliminate unattached cells and incubated with LPA $10 \mu \mathrm{M}$ for $18 \mathrm{~h}$ at $37^{\circ} \mathrm{C}$ in DMEM/F12 without fetal bovine serum. Cell migration was monitored at initial wounding $(t=0 \mathrm{~h})$ and at $18 \mathrm{~h}(t=18 \mathrm{~h})$ under a phase-contrast microscope (4×, IMT2 Olympus) and photographed with a digital camera (Olympus C-5060). The wound area was measured using the Image J (open source) software. Results were expressed as the percentage of cell migration (cell free area at $t=0 \mathrm{~h}-$ cell free area at $t=18 \mathrm{~h}$ ).

\subsection{Cell proliferation assay}

Proliferation was evaluated by using the soluble tetrazolium salt 3-(4,5-dimethylthiazol-2-yl)-2,5-diphenyltetrazolium bromide (MTT) colorimetric assay (Life Technologies, Argentina) as previously described. ${ }^{24}$ In living cells, MTT is reduced to formazan. Cells $\left(10^{4} /\right.$ well $)$ were seeded in 96-well plates in DMEM/F12 supplemented with 5\% fetal bovine serum and then left to adhere $4 \mathrm{~h}$. Subconfluent conditions of about $50-60 \%$ were chosen to allow detection of maximal growth. Cells were incubated with LPA $10 \mu \mathrm{M}$ for 
48 h. Supernatants were discarded, and viable cells were detected by adding $10 \mu \mathrm{L}$ of $5 \mathrm{mg} / \mathrm{mL}$ MTT in $100 \mu \mathrm{L}$ of medium free of phenol red supplemented with $3 \%$ fetal bovine serum. After incubation for $4 \mathrm{~h}$ at $37^{\circ} \mathrm{C}$ dimethyl sulfoxide $(50 \mu \mathrm{L})$ was added to solubilize the production of formazan. Formazan was evaluated by measuring the absorbance at $540 \mathrm{~nm}$ with an ELISA reader (BioTek). Values are mean \pm SEM and results are expressed as the absorbance obtained at $540 \mathrm{~nm}$ for solubilized formazan.

\subsection{COX-2 and iNOS immunocytochemistry}

HTR-8/SVneo cells $\left(50 \times 10^{3}\right)$ were grown to confluence on glass coverslips and incubated with LPA $10 \mu \mathrm{M}$ for $6 \mathrm{~h}$. Cells were fixed (10 $\mathrm{min}$, room temperature, $3.7 \% \mathrm{w} / \mathrm{v}$ paraformaldehyde) and permeabilized with $0.1 \%$ TRITON X-100 in PBS for $5 \mathrm{~min}$. Non-specific binding sites were blocked (60 min, $40 \mathrm{mg}$ / $\mathrm{mL}$ BSA in PBS). Slices were incubated overnight at $4{ }^{\circ} \mathrm{C}$ with anti-COX-2 (1:100, mouse polyclonal antibody, catalog \# 160126, Cayman Chemical) or anti-iNOS (1:100, polyclonal antibody, catalog \# 160826, Cayman Chemical). Afterwards, cells were incubated for $60 \mathrm{~min}$ at room temperature with AlexaFluor 555 goat anti-rabbit IgG (1:500, Abcam, Tecnolab, Buenos Aires, Argentina). Immunoreactive specificity was assessed by omitting the first antibody. Finally, cells were mounted on glass-slices using DABCO mounting medium (Sigma, Buenos Aires, Argentina) and observed by fluorescence microscopy at 100x (Nikon Eclipse 200).

\section{8 iNOS detection by Western blot}

HTR-8/SVneo cells $\left(400 \times 10^{3}\right)$ were grown to confluence in 6 -well plates and incubated with LPA $10 \mu \mathrm{M}$ for $24 \mathrm{~h}$. Cells were incubated for $5 \mathrm{~min}$ in modified RIPA buffer containing Tris-Cl $\mathrm{pH}=8$ with SDS $0.1 \% \mathrm{w} / \mathrm{v}$, Nonidet P-40 1\% v/v, sodium deoxycholate $0.5 \% \mathrm{v} / \mathrm{v}, \mathrm{NaCl} 150 \mathrm{mM}$, sodium ortovanadate $2 \mathrm{mM}$, protease inhibitor 10\% (Sigma, Buenos Aires, Argentina). Cells were scratched and centrifuged at $4^{\circ} \mathrm{C}$ for $10 \mathrm{~min}$ at $10000 \mathrm{rpm}$. Protein determination was assayed by the Bradford method ${ }^{25}$ using bovine serum albumin as standard. Equal amount of proteins (100 $\mu \mathrm{g} / \mathrm{lane})$ were separated in $10 \% \mathrm{w} / \mathrm{v}$ SDS-PAGE $(15 \mathrm{~mA}$ at room temperature) and subsequently transferred to nitrocellulose membranes $\left(110 \mathrm{~V}\right.$ at $4^{\circ} \mathrm{C}$ for $90 \mathrm{~min}$ ). Specific positive control was also loaded. ${ }^{26}$ Non-specific binding sites of the membranes were blocked using with $5 \%$ cold fish skin gelatin. Membranes were incubated with iNOS primary antibody $\left(1: 150,4^{\circ} \mathrm{C}, 18 \mathrm{~h}\right.$, Cayman) followed by a goat anti-rabbit horseradish peroxidase conjugated IgG (1:5000, room temperature, $1 \mathrm{~h}$, Jackson ImmunoResearch Laboratories, Inc, Georgia, Sero-immuno diagnostics, Inc.). Both the first and the second antibodies were diluted in PBS. Non-specifically bound antibody was removed by washing three times with PBS containing
Tween-20 0.1\% v/v. Immunoreactive bands were visualized by enhanced chemoluminescence reagents following the manufacturer's instructions. Immunoreactive specificity was assessed by omitting the first antibody. Protein bands were identified by molecular weight markers. b-actin was used as loading control (1:2500, room temperature, $1 \mathrm{~h}$, Sigma, Buenos Aires, Argentina). The intensity of bands was determined using the Image $\mathrm{J}$ software package (open source). Results were expressed as relative optic density iNOS/ $\beta$-actin.

\section{9 | Statistical analyses}

All values represent mean \pm S.E.M. Data were normally distributed according to the Shapiro-Wilk normality test. Comparisons between values of different groups were performed using analysis of variance (ANOVA) and significance was determined using post hoc tests Bonferroni or Tukey. A number of three replicates were used per treatment and each experiment was repeated 4-6 times. Differences between means were considered significant when $P<0.05$. Statistical analysis was performed using the InfoStat Program (Córdoba, Argentina).

\section{3 | RESULTS}

\section{1 | LPA stimulates first trimester trophoblast tubulogenesis, migration, and proliferation}

HTR-8/SVneo was incubated with LPA $(5,10,20$, and $50 \mu \mathrm{M})$ for $6 \mathrm{~h}$ and assayed for tube formation. First, we observed that LPA provoked a concentration-response effect (Figure 1A). Incubation with LPA at 5, 10, and $20 \mu \mathrm{M}$ increased trophoblast tube formation while LPA $50 \mu \mathrm{M}$ did not exert any effect. LPA $10 \mu \mathrm{M}$ was the lowest concentration that stimulate both tubule length and the number of branches, and it was selected for future experiments. Actin filament polymerization and wound healing assay were used to study migration in trophoblast cells incubated with LPA. LPA $10 \mu \mathrm{M}$ caused a rearrangement of the actin filaments compared to the control (Figure 1B), and this change was characterized by the elongation of stress fibers. In addition, incubation of HTR-8/SVneo cells with LPA $10 \mu \mathrm{M}$ stimulated wound closure (Figure 1C). MTT assay showed that LPA augmented trophoblast proliferation (Figure 1D). These results demonstrate that LPA increases trophoblast tube formation, migration and proliferation, suggesting that LPA would promote endovascular trophoblast adaptations involved in spiral artery remodeling at the maternal-fetal interface.

\section{2 $\mid \mathrm{LPA}_{3}$ mediates LPA stimulation on trophoblast tube formation}

Using RT-PCR for detection of $\mathrm{LPA}_{1}$ and $\mathrm{LPA}_{3}$ mRNA, we found that both receptors were expressed in the human first 
(A)

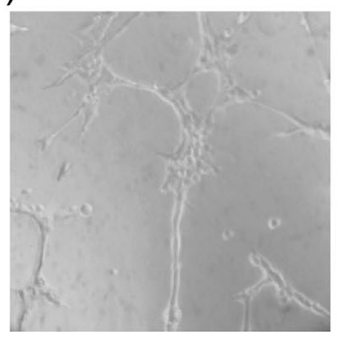

LPA $50 \mu \mathrm{M}$
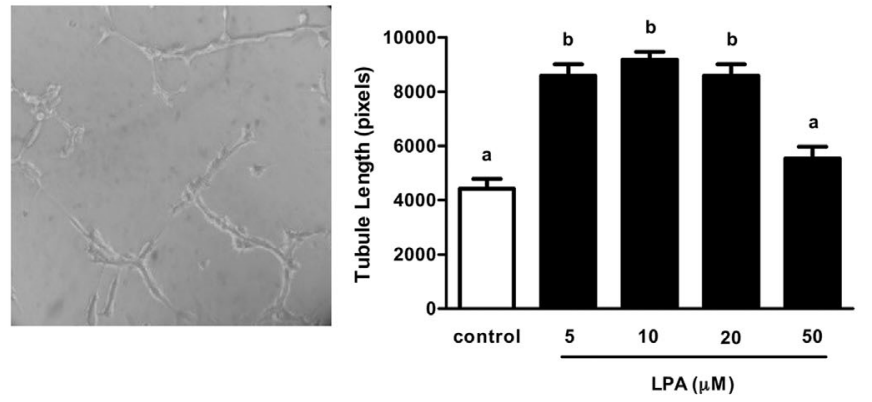

(B)

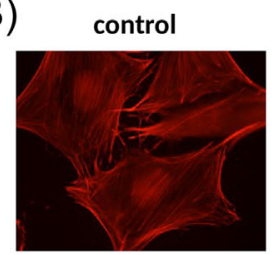

LPA $10 \mu \mathrm{M}$

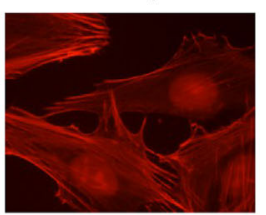

LPA $5 \mu \mathrm{M}$

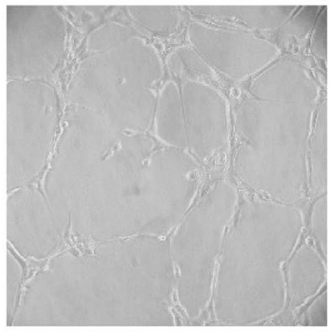

(C)

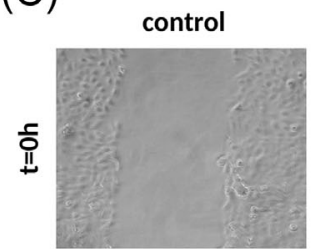

LPA $10 \mu \mathrm{M}$
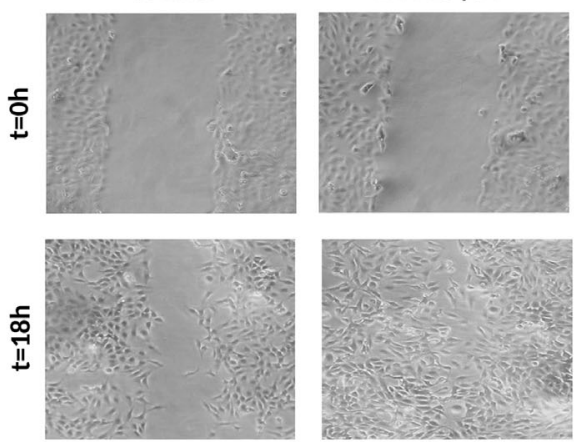

LPA $10 \mu \mathrm{M}$

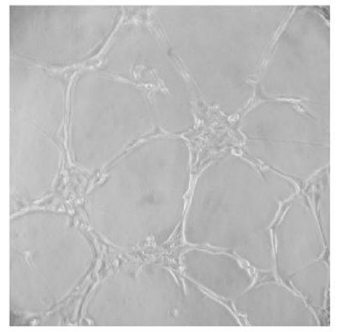

LPA $20 \mu \mathrm{M}$

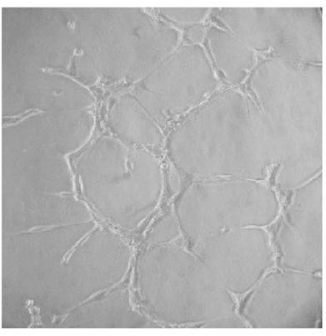

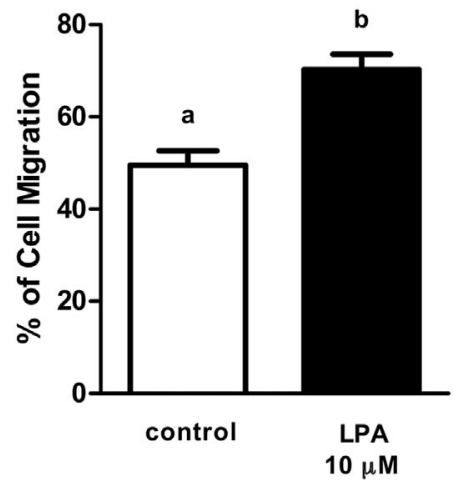

(D)

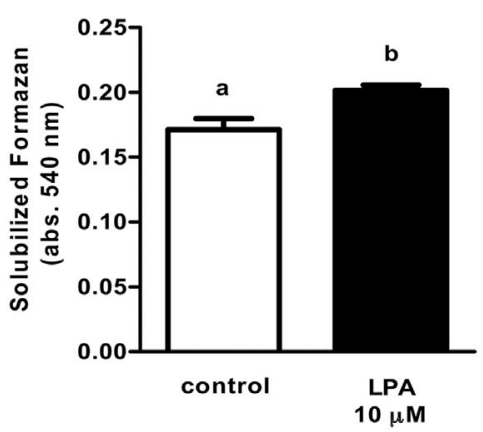

FIGURE 1 LPA promotes trophoblast tube formation, migration and proliferation. A, HTR-8/SVneo cells were seeded onto Geltrex and incubated for $6 \mathrm{~h}$ in the presence of medium (control) or LPA $(5,10,20$, and $50 \mu \mathrm{M})$. Representative photographs are shown $(10 \times)$. B, Effect of LPA $10 \mu \mathrm{M}$ on actin polymerization. Representative images of actin filaments stained with TRITC-phalloidin after $6 \mathrm{~h}$ of incubation with LPA and photographed under a fluorescent microscope $(100 \times)$. C, Effect of LPA $10 \mu \mathrm{M}$ on wound healing (18 h) of trophoblast cells. Representative images $(4 \times)$ at 0 and $18 \mathrm{~h}$. D, Cells were treated with LPA $10 \mu \mathrm{M}$ for $48 \mathrm{~h}$ and tested for proliferation by the MTT colorimetric assay. Results are expressed as the absorbance detected at $540 \mathrm{~nm}$ for solubilized formazan. Data represent mean \pm S.E.M. Different letters indicate statistical differences $(P<0.05)$. Three replicates per treatment, each experiment were repeated 4-6 times 
trimester trophoblast cell line (Figure 2A). Afterwards, we investigated which receptors mediated LPA effect. Cells were incubated for $6 \mathrm{~h}$ with LPA $10 \mu \mathrm{M}$ alone, LPA + DGPP $100 \mu \mathrm{M}$ (a selective $\mathrm{LPA}_{3}$ antagonist), LPA + BrP-LPA $5 \mu \mathrm{M}$ (a broad

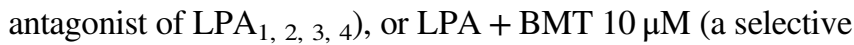
$\mathrm{LPA}_{1}$ antagonist). We observed that DGPP reversed LPA stimulation to control levels (Figure 2B). DGPP is a highly potent and selective antagonist for $\mathrm{LPA}_{3}(\mathrm{Ki}=106 \mathrm{nM})$ and exerts low affinity for $\mathrm{LPA}_{1}(\mathrm{ki}=6.6 \mu \mathrm{M})$. To confirm that $\mathrm{LPA}_{3}$ was the receptor involved in LPA effect, HTR-8/SVneo cells were incubated with LPA + BrP-LPA or with LPA + BMT. BrP-LPA reversed LPA stimulation to control levels (Figure 2B), as observed with DGPP. However, BMT did not modify LPA action (Figure 2B). The antagonists did not exert any effect per se on trophoblast tubulogenesis (Supplementary Fig. SI). Hence, LPA stimulates trophoblast capillary response through $\mathrm{LPA}_{3}$.

\subsection{COX-2 and iNOS participate in LPA increase trophoblast tubulogenesis}

In order to study if COX or NOS pathways were involved in the action of LPA on trophoblast tube formation, HTR-8/SVneo cells were incubated for $6 \mathrm{~h}$ with LPA $10 \mu \mathrm{M}$ alone, LPA + indomethacin $10 \mu \mathrm{M}$ (a non-selective COX-1 and COX-2 inhibitor), LPA + NS-398 $1 \mu \mathrm{M}$ (a selective COX-2 inhibitor), LPA + LNAME $10 \mu \mathrm{M}$ (a non-selective NOS inhibitor), or LPA $+1400 \mathrm{~W}$ $10 \mu \mathrm{M}$ (a selective iNOS inhibitor). The incubation of LPA with indomethacin or with NS-398 reversed LPA stimulation to control levels (Figure 3A). Similarly, both L-NAME and $1400 \mathrm{~W}$ blocked LPA increased tube formation to the basal (Figure 3B). The non-selective and selective inhibitors did not show any effect on basal tube formation (Supplementary Fig. SII). Overall our results demonstrate that LPA increases trophoblast tubulogenesis through COX-2 and iNOS pathways.

(A)

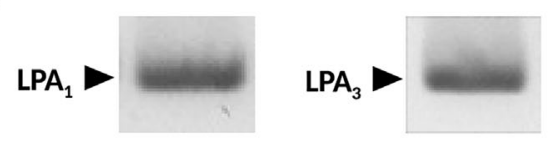

(B)
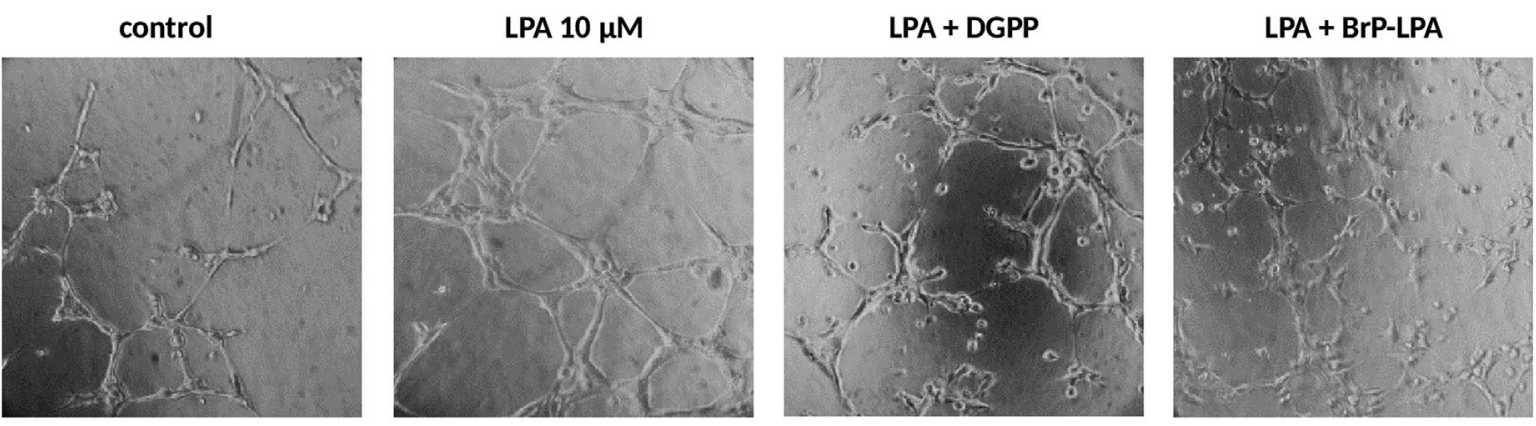

LPA + BMT
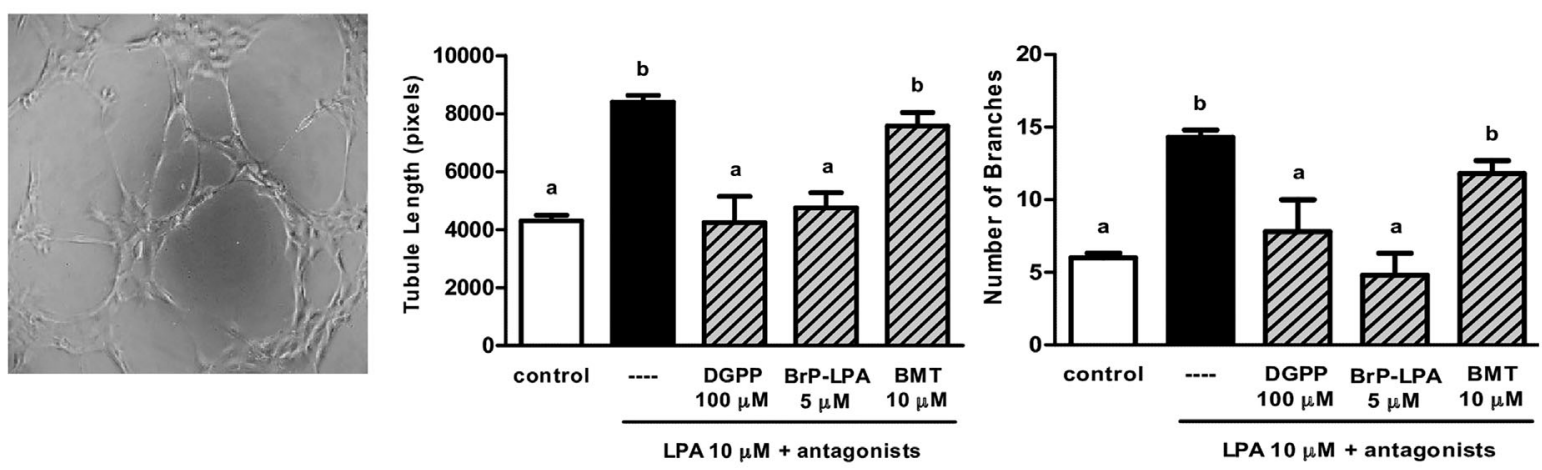

FIGURE $2 \mathrm{LPA}_{3}$ mediates LPA stimulatory effect on trophoblast tubulogenesis. A, HTR-8/SVneo cells expressed LPA 1 and LPA $\mathrm{mRNA}$ Representative photograph is shown. B, HTR-8/SVneo cells were seeded onto Geltrex and incubated for $6 \mathrm{~h}$ with LPA $10 \mu \mathrm{M}$, LPA + DGPP $100 \mu \mathrm{M}$ (a selective $\mathrm{LPA}_{3}$ antagonist), LPA + BrP-LPA $5 \mu \mathrm{M}$ (a broad antagonist of $\mathrm{LPA}_{1,2,3,4}$ ) or LPA + BMT $10 \mu \mathrm{M}($ a selective LPA antagonist). Representative photographs are shown $(10 \times)$. Data represent mean \pm S.E.M. $(P<0.05)$. Three replicates per treatment, each experiment were repeated $4-6$ times 
(A)

control
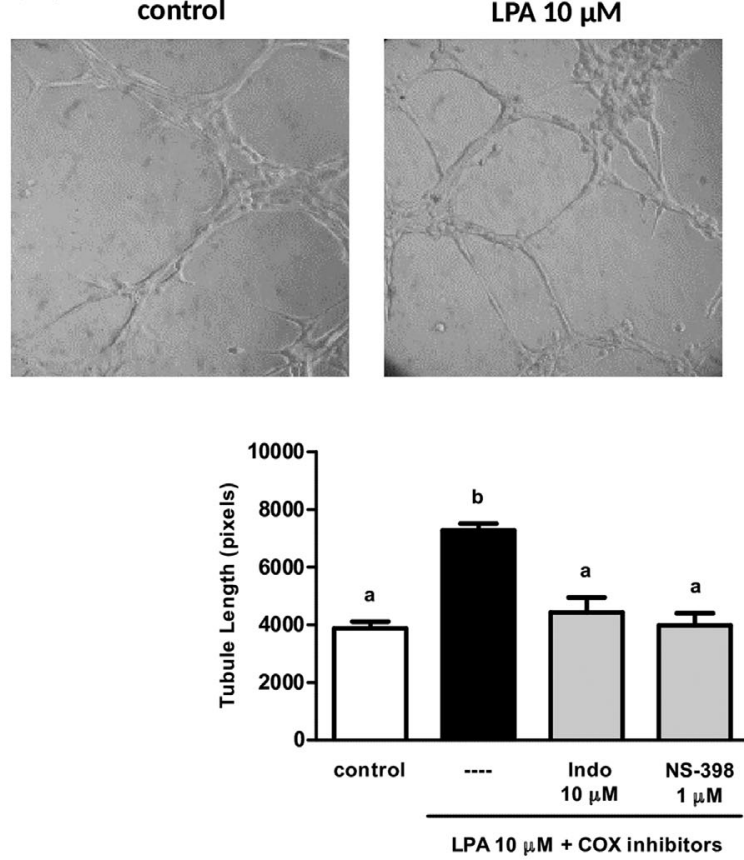

LPA + Indo
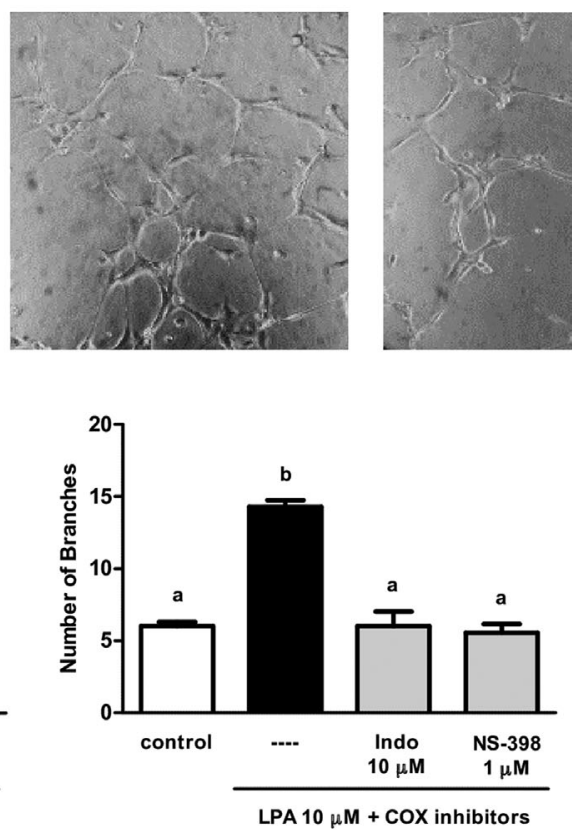

(B)

control

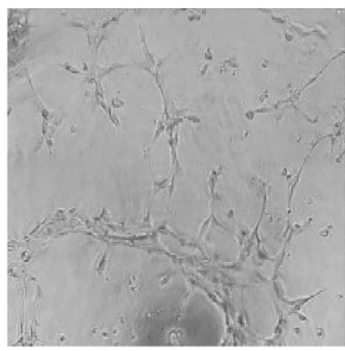

LPA $10 \mu \mathrm{M}$

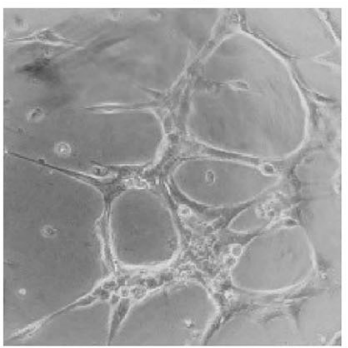

LPA + L-NAME

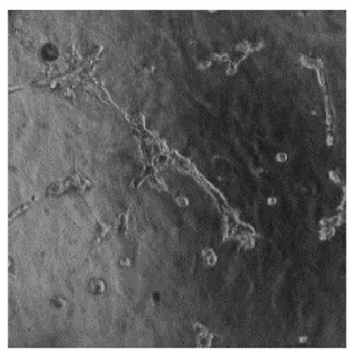

LPA + NS-398

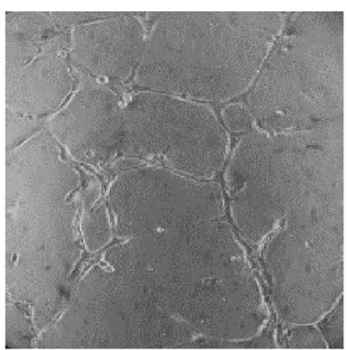

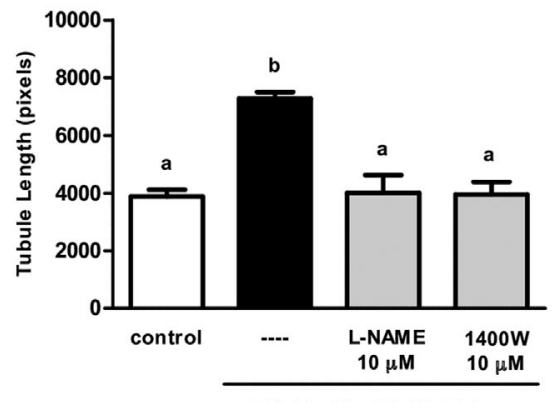

LPA $10 \mu \mathrm{M}+$ NOS inhibitors

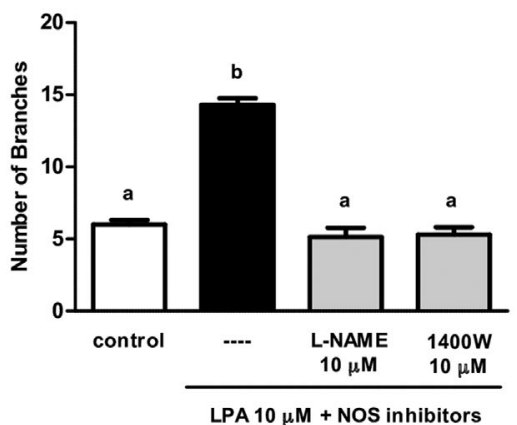

FIGURE 3 COX-2 and iNOS participate in LPA increased trophoblast tubulogenesis. HTR-8/SVneo cells were seeded onto Geltrex and treated for $6 \mathrm{~h}$ as specified. A, Cells were incubated with LPA $10 \mu \mathrm{M}$, LPA + indomethacin $10 \mu \mathrm{M}$ (a non-selective COX-1 and COX-2 inhibitor) or LPA + NS-398 $1 \mu \mathrm{M}$ (a selective COX-2 inhibitor). B, Cells were incubated with LPA $10 \mu \mathrm{M}$, LPA + L-NAME $10 \mu \mathrm{M}$ (a non-selective NOS inhibitor) or LPA +1400W $10 \mu \mathrm{M}$ (a selective iNOS inhibitor). Representative photographs are shown $(10 \times)$. Data represent mean \pm S.E.M. $(P<0.05)$. Three replicates per treatment, each experiment was repeated 4-6 times. Indo: indomethacin 

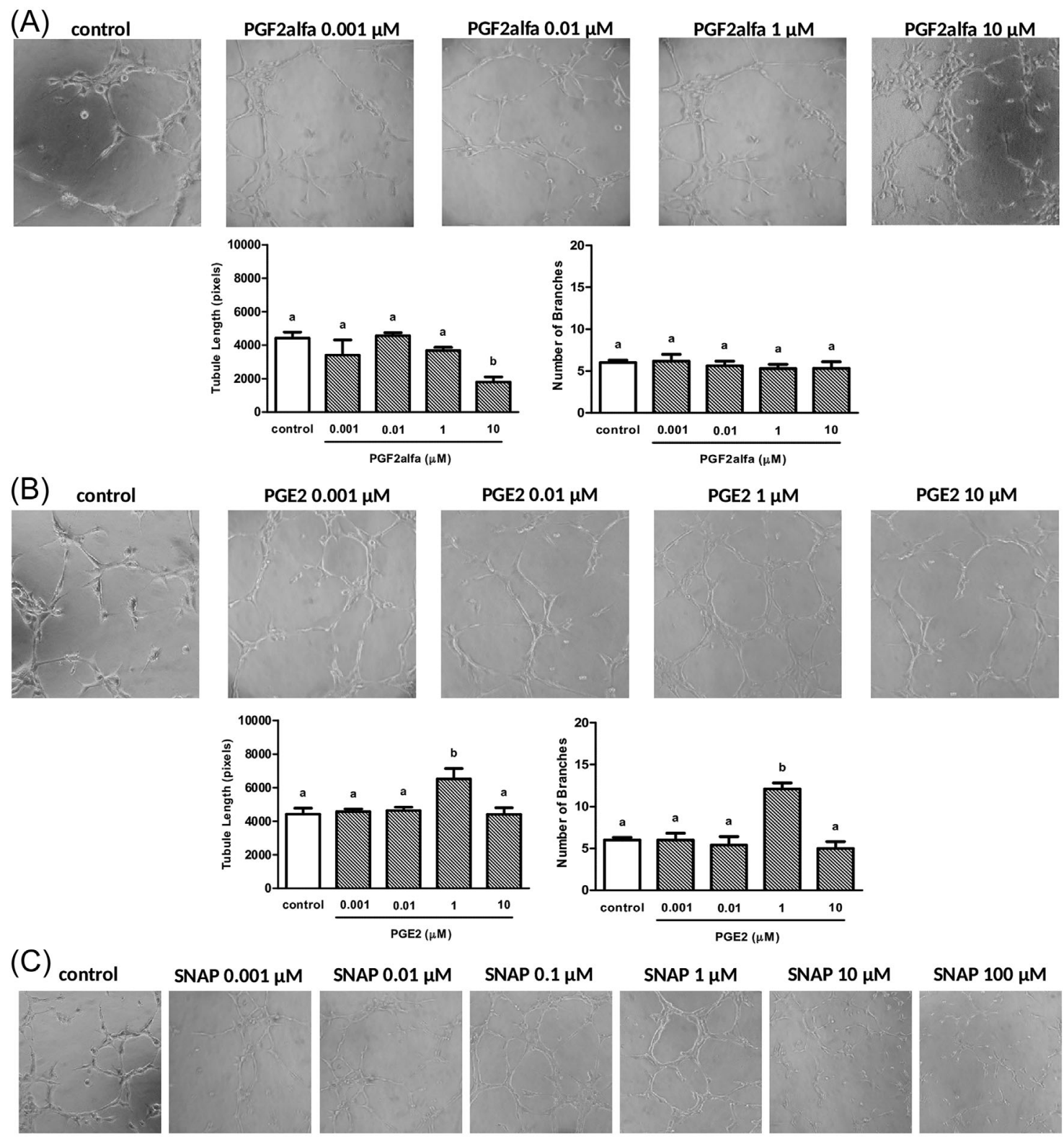

SNAP $100 \mu \mathrm{M}$
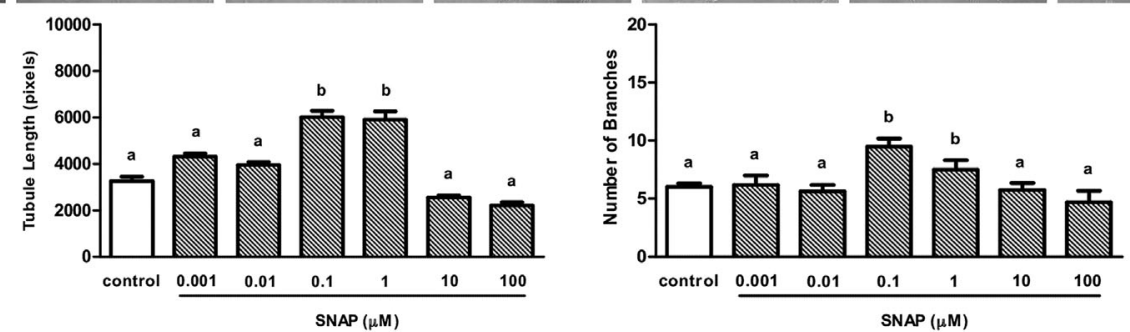

FIGURE 4 Concentration-response effect of prostaglandin E2, prostaglandin F2alfa, and SNAP on trophoblast tubulogenesis. HTR-8/SVneo cells were seeded onto Geltrex and treated for $6 \mathrm{~h} \mathrm{~A}$, prostaglandin F2alfa $(0.001,0.01,1$, and $10 \mu \mathrm{M})$, B, with prostaglandin E2 (0.001, 0.01, 1, and $10 \mu \mathrm{M})$, or $\mathrm{C}$, with SNAP $(0.001,0.01,0.1,1,10$, and $100 \mu \mathrm{M})$. Representative photographs are shown $(10 \times)$. Data represent mean \pm S.E.M. $(P<0.05)$. Three replicates per treatment, each experiment was repeated 4-6 times

Based on these findings, we decided to test if prostaglandins and nitric oxide could stimulate trophoblast capillary-like structures. HTR-8/SVneo cells were incubated for $6 \mathrm{~h}$ with prostaglandin F2alfa $(0.001,0.01,1$, and $10 \mu \mathrm{M})$, prostaglandin E2 $(0.001,0.01,1$, and $10 \mu \mathrm{M})$, or SNAP $(0.001,0.01,0.1,1,10$, and $100 \mu \mathrm{M})$. SNAP releases nitric oxide under physiological conditions, making it a useful tool for studying pharmacological and physiological actions of 


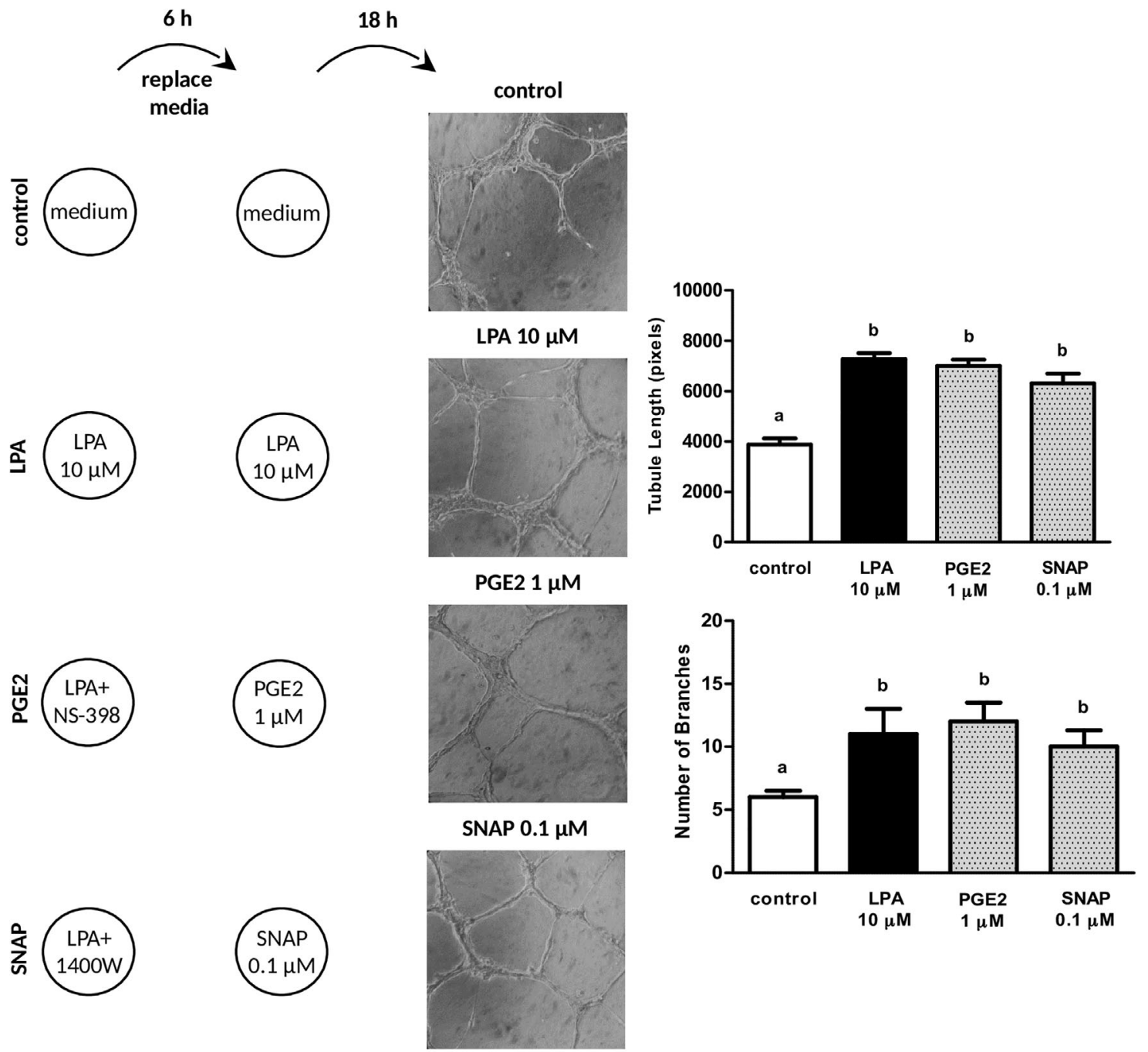

FIGURE 5 PGE2 and SNAP rescue the inhibition caused by NS-398 and $1400 \mathrm{~W}$ during LPA increased trophoblast tubulogenesis. The scheme represents the experimental procedure of the lineal rescue. Cells were incubated for $6 \mathrm{~h}$ with LPA $10 \mu \mathrm{M}$, LPA + NS-398 $1 \mu \mathrm{M}$, or $\mathrm{LPA}+1400 \mathrm{~W} 10 \mu \mathrm{M}$. Supernatants were removed and the cells were incubated for $18 \mathrm{~h}$ with LPA $10 \mu \mathrm{M}$, prostaglandin E2 $1 \mu \mathrm{M}$ or SNAP $0.1 \mu \mathrm{M}$, respectively. Representative photographs are shown $(10 \times)$. Data represent mean \pm S.E.M. Different letters indicate statistical differences. $(P<0.05)$. Three replicates per treatment, each experiment was repeated 4-6 times

nitric oxide. While prostaglandin F2alfa did not modify trophoblast tube formation (Figure 4A), prostaglandin E2 (Figure 4B) and SNAP (Figure 4C) exerted a concentrationresponse action. Prostaglandin E2 $1 \mu \mathrm{M}$ and SNAP $0.1 \mu \mathrm{M}$ were the lowest concentrations eliciting a stimulatory effect on trophoblast capillary-like structures. These results suggest that prostaglandin $\mathrm{E} 2$ from $\mathrm{COX}-2$ and nitric oxide produced by iNOS mediate the stimulatory effect of LPA on trophoblast tube formation. Thus, we decided to test if prostaglandin E2 or SNAP could restore the inhibition caused by COX-2 or iNOS inhibitors on LPA stimulation (lineal rescue). Therefore, HTR-8/SVneo cells were incubated for $6 \mathrm{~h}$ with LPA $10 \mu \mathrm{M}, \quad \mathrm{LPA}+\mathrm{NS}-3981 \mu \mathrm{M}$, or $\mathrm{LPA}+1400 \mathrm{~W} 10 \mu \mathrm{M}$. Afterwards, the supernatants were removed, and the cells were incubated for $18 \mathrm{~h}$ with LPA $10 \mu \mathrm{M}$, prostaglandin
E2 $1 \mu \mathrm{M}$ or SNAP $0.1 \mu \mathrm{M}$ (Figure 5). We observed that both prostaglandin E2 and SNAP rescued the cells from the inhibition caused by NS-398 or $1400 \mathrm{~W}$, respectively (Figure 5). These results were not a wash-out effect of the inhibitors as LPA could not surpass the initial inhibition (Supplementary Fig. SIII).

\section{4 | COX-2 stimulatiois upstream iNOS signaling during LPA effect}

We investigated which regulatory pathway, COX-2 or iNOS, was stimulated first under LPA action. HTR-8/SVneo cells were treated for $6 \mathrm{~h}$ with LPA $10 \mu \mathrm{M}, \mathrm{LPA}+1400 \mathrm{~W} 10 \mu \mathrm{M}$ or LPA + NS-398 $1 \mu \mathrm{M}$, and the supernatants were removed. The cells pre-treated with LPA alone were incubated with 
(A)
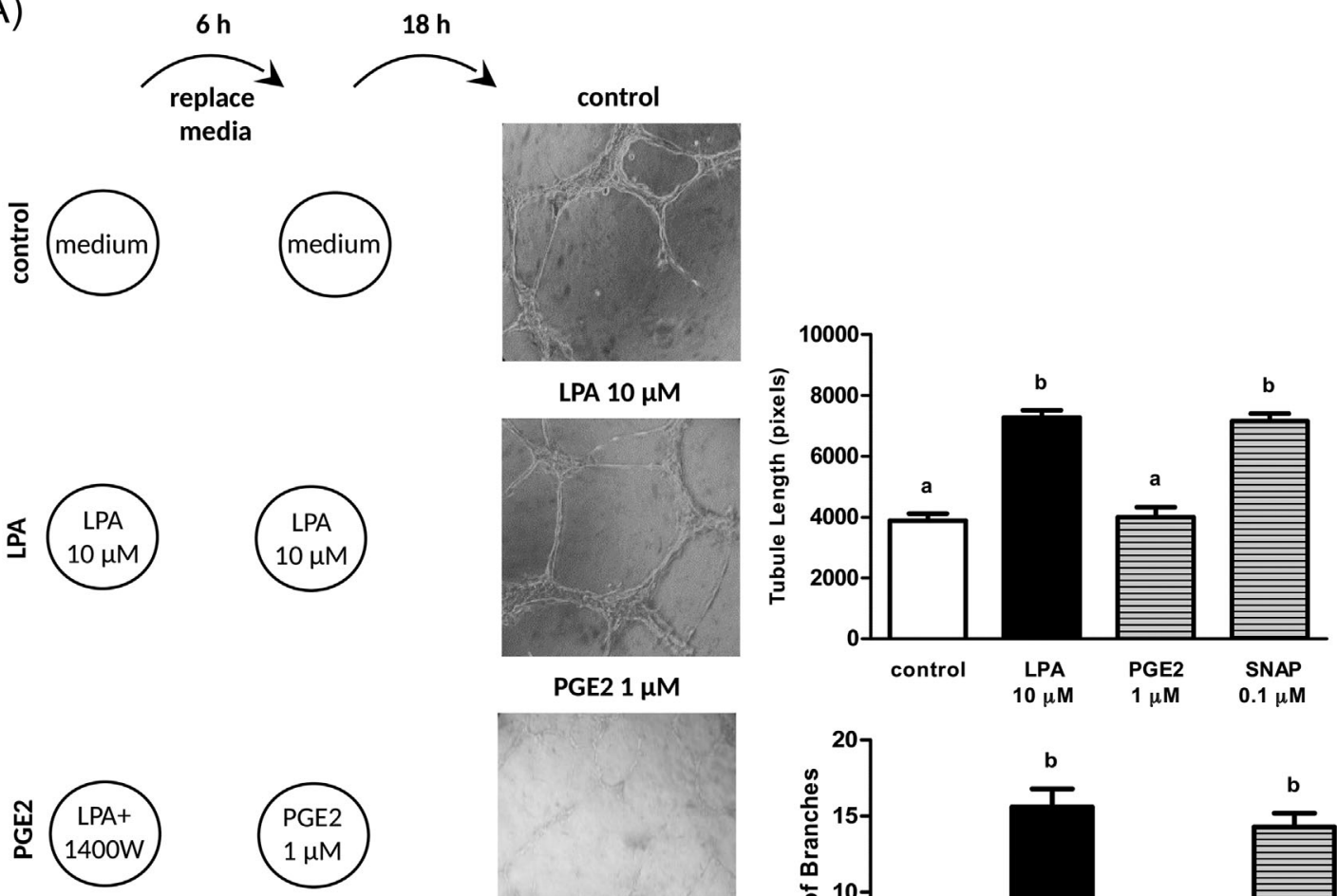

LPA $10 \mu \mathrm{M}$
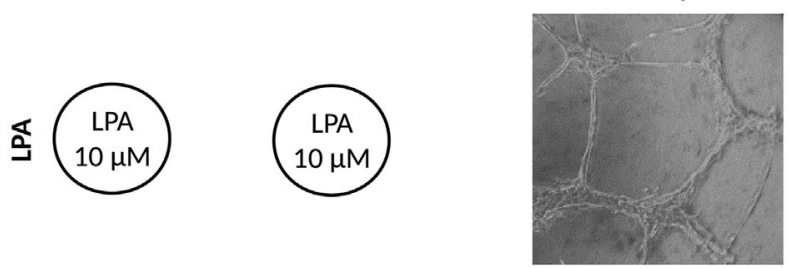

PGE2 $1 \mu \mathrm{M}$

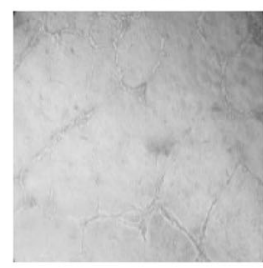

SNAP $0.1 \mu \mathrm{M}$
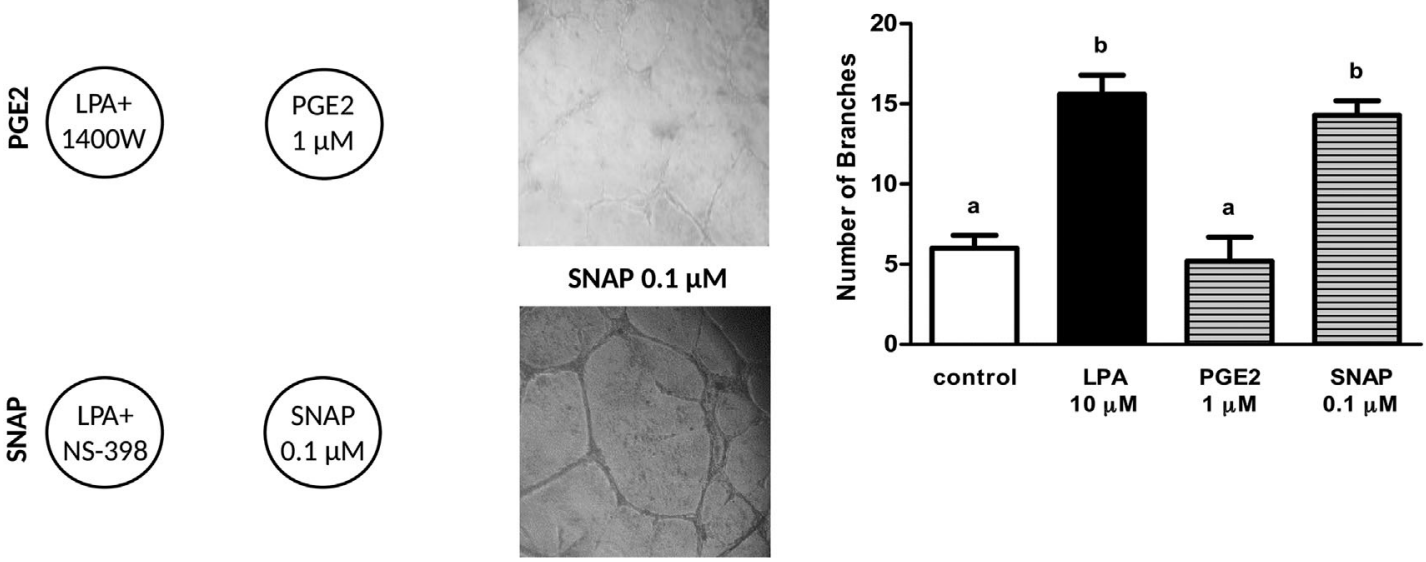

(B)
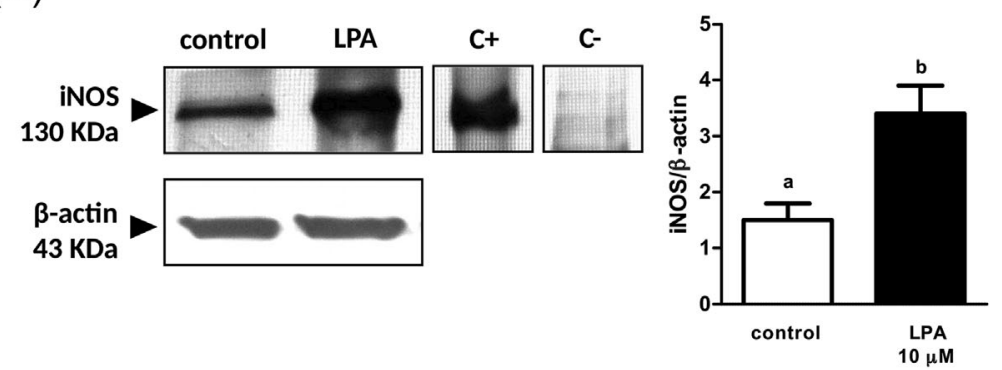

FIGURE 6 COX-2 is stimulated before iNOS during LPA stimulated trophoblast tubulogenesis. LPA increased iNOS expression. A, The scheme represents the experimental procedure of the cross rescue. HTR-8/SVneo cells were treated for $6 \mathrm{~h}$ with LPA $10 \mu \mathrm{M}, \mathrm{LPA}+1400 \mathrm{~W}$ $10 \mu \mathrm{M}$ or LPA + NS-398 $1 \mu \mathrm{M}$. Supernatants were removed and the cells pre-treated with LPA alone were incubated with LPA $10 \mu \mathrm{M}$, those pretreated with LPA $+1400 \mathrm{~W}$ were incubated with prostaglandin E2 $1 \mu \mathrm{M}$, and the cells pre-treated with LPA + NS-398 were incubated with SNAP $0.1 \mu \mathrm{M}$. After $18 \mathrm{~h}$, tubulogenesis was observed under an inverted microscope. Representative photographs are shown $(10 \times)$. Data represent mean \pm S.E.M. Different letters indicate statistical differences $(P<0.05)$. Three replicates per treatment, each experiment was repeated 4-6 times. B, iNOS protein expression was detected by Western blot. Proteins from HTR-8/SVneo were extracted and separated by SDS-PAGE and immunoblotted with a specific antibody against iNOS. The figure is representative of three independent experiments. C+: positive control (mice uteri treated with lipopolysaccharide), $\mathrm{C}-$ : negative control. Data represent mean \pm S.E.M. Different letters indicate statistical differences $(P<0.05)$. 
(A)
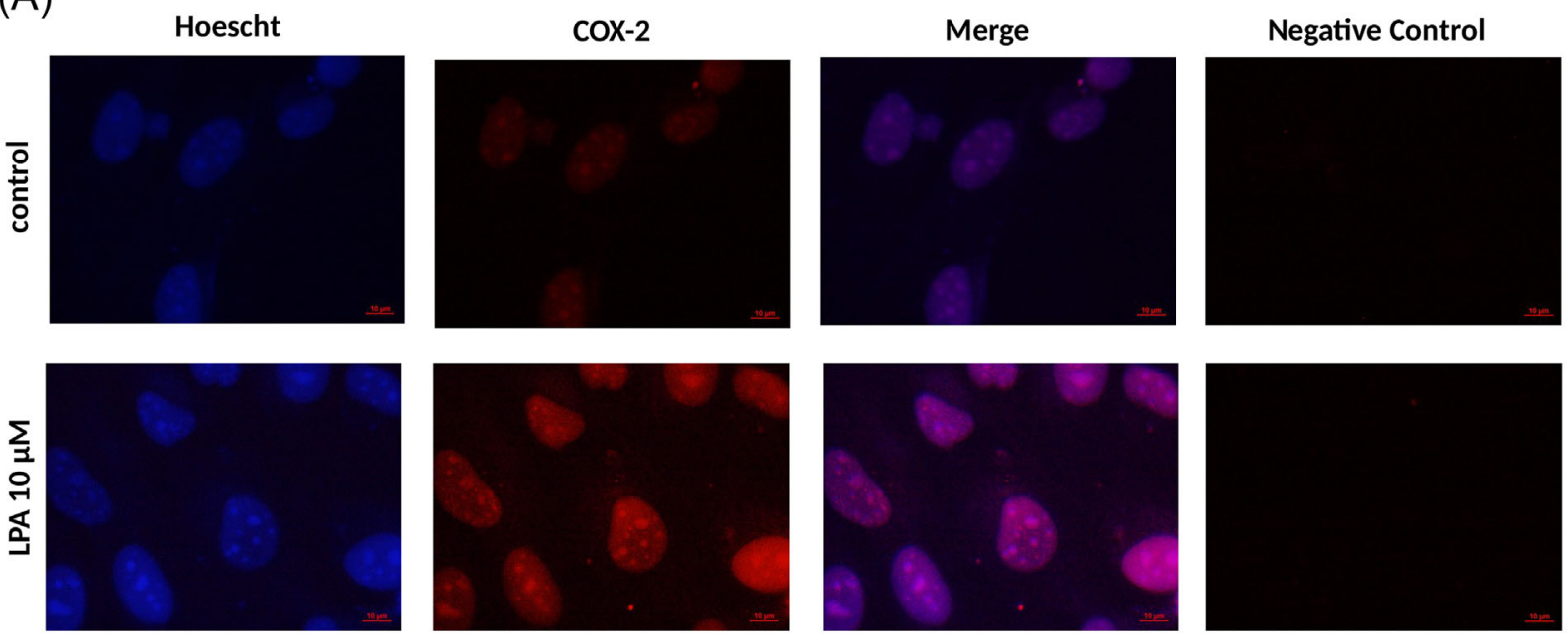

(B)

Hoescht

iNOS
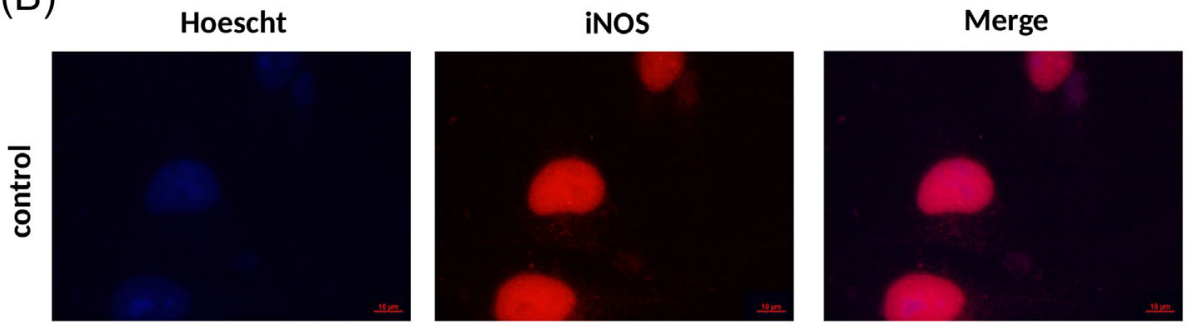

Negative Control
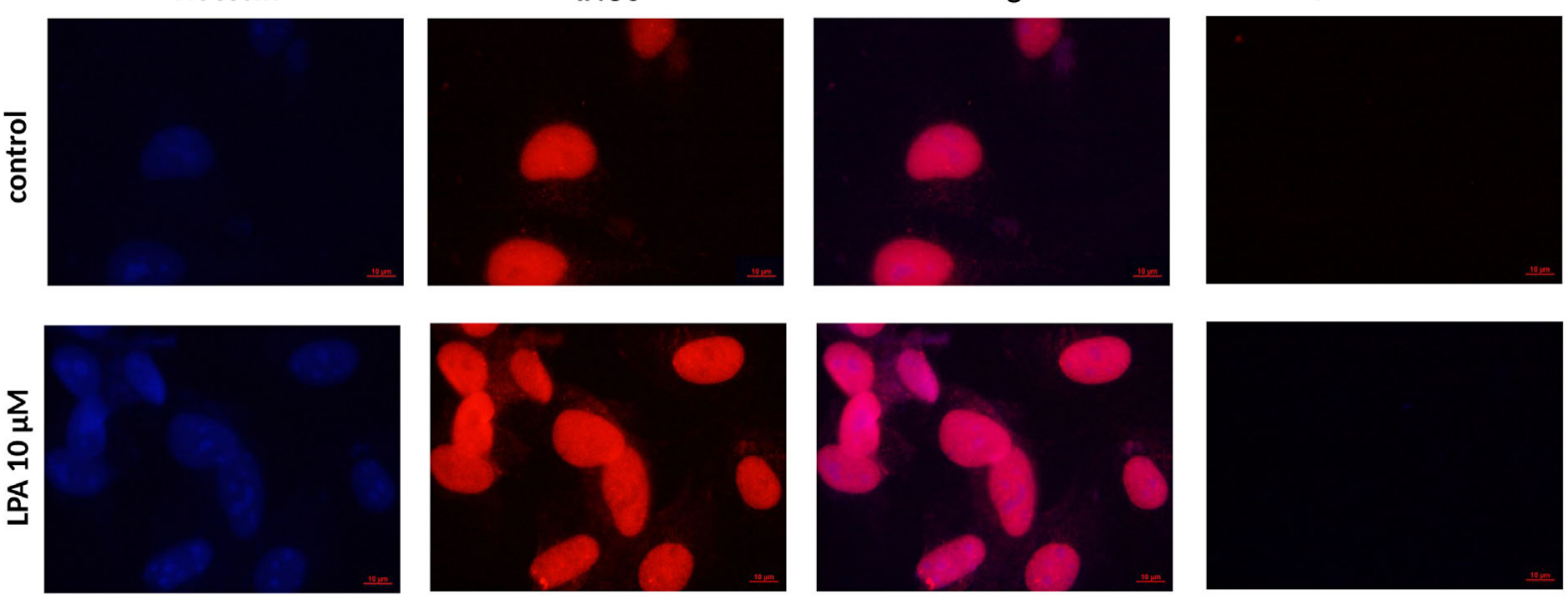

FIGURE 7 COX-2 and iNOS proteins are localized in the trophoblast nucleus. HTR-8/SVneo cells were incubated for $6 \mathrm{~h}$ with LPA $10 \mu \mathrm{M}$ and stained for (A) COX-2 (1:100) or (B) iNOS (1:100) by immunofluorescence. Immunoreactive specificity was assessed by omitting the first antibody. Representative images are shown (scale bar: $10 \mu \mathrm{m}$ ). Nucleus stained with Hoescht showed blue, iNOS and COX-2 appeared as red signals. In the merge panels overlapping blue and red labelings are shown. The experiment was performed in triplicate

LPA $10 \mu \mathrm{M}$, those pre-treated with LPA $+1400 \mathrm{~W}$ were incubated with prostaglandin E2 $1 \mu \mathrm{M}$, and the cells pretreated with LPA + NS-398 were incubated with SNAP $0.1 \mu \mathrm{M}$ (cross rescue). After $18 \mathrm{~h}$, the tubule length and the number of branches were determined. We observed that the incubation with prostaglandin E2 did not modify the inhibitory effect caused by $1400 \mathrm{~W}$ (Figure 6A). However, SNAP rescued the cells from the inhibition caused by NS-398 on trophoblast tubulogenesis, and reached values similar to LPA alone (Figure 6A). Therefore, while the nitric oxide donor could overpass the selective COX-2 inhibition, prostaglandin E2 did not modify the action exerted by the selective iNOS inhibitor. This result shows that COX-2 is stimulated upstream iNOS under LPA-increased trophoblast tubulogenesis. Moreover, LPA $10 \mu \mathrm{M}$ increased iNOS expression in HTR-8/SVneo cells (Figure 6B). Finally, we studied COX-2 and iNOS localization. We observed that first trimester trophoblast express COX-2 and iNOS isoforms mainly in the nucleus, and the treatment with LPA $10 \mu \mathrm{M}$ did not change their localization (Figure 7).

\section{4 | DISCUSSION}

The establishment of successful pregnancy requires remodeling of maternal blood vessels and the proper coordination of vascular processes at the maternal-fetal interface. During the first trimester of gestation, the extravillous trophoblast 
acquires an endovascular phenotype and remodels maternal vessels. Deregulation of the spiral artery adaptations impairs the supply of nutrient and oxygen to the embryo, and has a major clinical impact resulting in several pregnancy complications, as implantation failure and preeclampsia. Due to difficulties in studying early human pregnancy, little is known about the regulatory pathways that modulate the endovascular trophoblast and contribute to spiral artery remodeling.

The early stages of spiral artery remodeling are considered to resemble angiogenesis (ie, vessel dilation, increased permeability, loss of vascular smooth muscle). It is proposed that the endovascular trophoblast, which orchestrate maternal vessel adaptations in the first trimester of gestation, assume an angiogenic phenotype, and become part of the endothelial layers. The replacement of decidual endothelial cells by extravillous trophoblast may involve the disruption of inter-endothelial cell junctions, which can cause destabilization of the endothelial cells. In addition, different cytokines, including IL-6, IL-8, and IFN- $\gamma$, may influence endothelial integrity, resulting in endothelial barrier dysfunction and vascular permeability. Preeclamptic placenta express severe alterations in endothelial cells. ${ }^{27}$ Extravillous trophoblast could diminish the barrier function of endothelial cells, and endothelial tight junctions are more susceptible to preeclamptic trophoblast than to normal trophoblast cells. ${ }^{28}$ Also, Fraser et $\mathrm{al}^{29}$ observed that disruption of endothelial structures is impaired in pregnant women with high resistance indices, that are related to the extent of spiral artery remodeling.

Development of endothelial-like structures on tube formation assay facilitates the study of angiogenesis pathways that cannot be easily measured in vivo. The formation of interconnecting capillary-like structures in vitro is not specific to endothelial cells but requires an acquisition of an endothelial cell phenotype on a basement membrane. Tubulogenesis is an extremely specific process that replicates multiple steps in angiogenesis, like adhesion, alignment, and tube formation. Here, we investigated different aspects of angiogenesis in vitro as tubulogenesis, migration, and proliferation in the presence of LPA in human first trimester trophoblast. We used the HTR-8/SVneo cell line as a tool to model the acquisition of the endovascular phenotype by the invading trophoblast. We show that LPA stimulates the formation of capillary-like tubes in this cytotrophoblast cell line, and that LPA also increases first trimester trophoblast migration and proliferation. It has been proposed that these processes reflect placental angiogenesis, endovascular differentiation and acquisition of an endothelial phenotype by the trophoblast. ${ }^{30-34}$ Furthermore, Highet et $\mathrm{al}^{35}$ recently published that HTR-8/SVneo cells forming tubes express a gene profile similar to endothelial cells undergoing angiogenesis (ie, EDN1, TGF- $\beta 2$, BMP4, EDNRA, and ANGPTL4). Based on these findings we propose a new role for LPA in the regulation of the endovascular trophoblast adaptations involved in spiral artery remodeling at the maternal-fetal interface.

The relevance of LPA in trophoblast vascular responses at the maternal-fetal interface is supported by previous findings showing the expression of lysophospholipase-D (the main enzyme involved in LPA synthesis) in placental human trophoblast. ${ }^{36}$ Lysophospholipase-D activity increases in serum with the length of gestation, and produces micromolar levels of LPA. ${ }^{37}$ However, the activity of lysophospholipaseD decreases to non-pregnant levels soon after delivery. ${ }^{38}$ Therefore, the group of Iwasawa ${ }^{36}$ suggested that the principal source of LPA during gestation is the placental trophoblast.

Previous results from our own support the participation of LPA in vascular remodeling at the maternal-fetal interface. We recently reported that disruption of endogenous LPA modifies the development of uterine and arcuate arteries in pregnant rats, with severe consequences in placentation. ${ }^{7}$ In addition to these macrovascular changes, we observed disruptions in the microvasculature at the implantation sites (ie, fewer vessels with larger perimeter). Interestingly, patients displaying recurrent implantation failure show fewer vessels density with larger circumferences in the deciduas. ${ }^{3}$ Thus, the inadequate acquisition of the endovascular phenotype by the trophoblast due to abnormal LPA signaling may contribute to the development of pathologies related to impaired vascular remodeling.

Here, we demonstrate that LPA stimulates trophoblast capillary response through LPA3. We published that blocking $\mathrm{LPA}_{3}$ in vivo induces embryonic resorption associated to macro and microvascular changes in the rat uterus. ${ }^{7}$ In addition, Ye et $\mathrm{al}^{4}$ identified clear phenotypic changes in $\mathrm{LPA}_{3}$-deficient mice (ie, delayed implantation and embryo crowding). However, deletion of $\mathrm{LPA}_{1}$ and $\mathrm{LPA}_{2}$ reveals other roles for these receptors, without obvious effects on embryo implantation. ${ }^{39,40}$ Furthermore, patients displaying recurrent implantation failure express reduced levels of $\mathrm{LPA}_{3}$ in the endometrium. ${ }^{41}$ Therefore, $\mathrm{LPA}_{3}$ seems to be the subtype of LPA receptor with major participation during early gestation.

Prostaglandins derived from COX-2 activity play a fundamental role at the site of implantation regulating angiogenesis. ${ }^{10-12}$ We previously found that LPA stimulates COX-2-derived prostaglandins and interleukin-10 expression in the rat uterus during the window of implantation. ${ }^{6,16}$ Here, we described that COX-2 participates in LPA increased trophoblast tubulogenesis. In addition, immunocytochemistry experiments suggest an accumulation of nuclear COX-2 under LPA effect, and LPA does not modify its distribution. Other authors also informed that COX-2 presents a nuclear localization in endothelial cells from human umbilical vein, suggesting a role for this enzyme in regulating gene expression. ${ }^{42}$ More experiments are being performed to 
elucidate the molecular regulation of $\mathrm{COX}-2$ protein expression by LPA in first trimester trophoblast.

It is proposed that whereas prostaglandin E2 contributes to the process of maternal decidualization and angiogenesis, the increase in prostaglandin F2alpha promotes uterine contractions with negative consequences in the progression of pregnancy. ${ }^{43-45} \mathrm{We}$ observed that prostaglandin E2 promotes trophoblast capillary-like structures, while prostaglandin F2alpha does not modify them. Moreover, prostaglandin E2 rescues trophoblast tubulogenesis from COX-2 selective inhibition. Therefore, we speculate that prostaglandin E2 derived from COX-2 activity is the prostaglandin involved in LPA effect on trophoblast tube formation. In coincidence with this, we previously observed that LPA augments prostaglandin E2, but does not modify the production of prostaglandin F2alpha in the rat pregnant uterus. $^{6}$ Altogether, these results reinforce the importance of prostaglandin E2 in vascular remodeling processes that take place during the early stages of gestation.

Nitric oxide derived from NOS is a potent messenger that regulates vascular tone, angiogenesis, and cellular aggregation and adhesion, which are important functions in establishing and maintaining normal pregnancy. Regulation of nitric oxide concentrations at the maternal-fetal interface seems to be crucial for maintaining early gestation due to failures in vascular adaptations. ${ }^{14}$ Here, we describe that iNOS is localized in the nucleus and is the final effector in the signaling pathway triggered by LPA on trophoblast tube formation. Moreover, LPA increases iNOS protein expression. Pioneering experiments from Zhou et $\mathrm{al}^{1}$ show that nitric oxide promotes endovascular invasion by the cytotrophoblast. Interestingly, nitric oxide is produced by the trophoblast while invading the maternal spiral arteries in the wall of the uterus. ${ }^{46}$ Previous results from our own support these observations. We reported that NOS activity is higher in rat implantation sites and is differentially regulated by the blastocyst. ${ }^{13}$ In addition, we found that LPA stimulates specifically iNOS isoform in the rat uterus, and this pathway is involved in the increase of interleukin-10, a vascular marker. ${ }^{16}$ Other authors also described iNOS localization in extravillous trophoblast and sincitiotrophoblast. ${ }^{4-49}$ Using confocal microscopy, Cartwright et $\mathrm{al}^{50}$ show iNOS immunoreactive staining within the nucleus of SGHPL-4, a human first trimester trophoblast cell line. Our results are in accordance with other authors who demonstrate a specific role for nitric oxide in the physiological vascular adaptation of normal pregnancy. ${ }^{1,51,52}$ Together, these findings point out a protective role for nitric oxide on trophoblast vascular functions, and suggest that iNOS is the isoform involved in the induction of the endovascular phenotype at the maternal-fetal interface.

Overall, our results demonstrate that LPA promotes HTR8/SVneo tube formation, migration, and proliferation. Moreover, trophoblast tube formation is mediated by $\mathrm{LPA}_{3}$ and involves COX-2 and iNOS regulatory pathways. Nitric oxide seems to be the last effector. Endovascular extravillous trophoblast cells are crucial players in uterine vascular remodeling, and deficiencies in this process could lead to implantation failure and preeclampsia. We propose that LPA synthesized at the maternal-fetal interface induces the production of prostaglandin E2 and nitric oxide by iNOS, that being the last effector in this signaling pathway, promotes the acquisition of the endovascular phenotype by the trophoblast. Finally, this mechanism supports the invasion of the spiral arteries by the cytotrophoblast ensuring sufficient blood flow in response to the increasing metabolic demands of the embryo. Therefore, elucidating the interaction between LPA and the molecules regulated downstream during endovascular trophoblast adaptations at the maternal-fetal interface might help to prevent severe obstetric complications. Our findings contribute to better understand the significance of LPA signaling in the vascular events that lead to a successful pregnancy.

\section{ACKNOWLEDGMENTS}

BMT (BMT-183172-01-002) was kindly provided by Bristol Myers Squibb.

\section{DISCLOSURE}

None.

\section{REFERENCES}

1. Zhou Y, Fisher SJ, Janatpour M, et al. Human cytotrophoblasts adopt a vascular phenotype as they differentiate. A strategy for successful endovascular invasion? J Clin Invest. 1997a;99: 2139-2151.

2. Zhou Y, Damsky CH, Fisher SJ. Preeclampsia is associated with failure of human cytotrophoblasts to mimic a vascular adhesion phenotype. One cause of defective endovascular invasion in this syndrome? J Clin Invest. 1997b;99:2152-2164.

3. Plaisier M, Dennert I, Rost E, Koolwijk P, van Hinsbergh VW, Helmerhorst FM. Decidual vascularization and the expression of angiogenic growth factors and proteases in first trimester spontaneous abortions. Human Reprod. 2009;24:185-197.

4. Ye X, Hama K, Contos JJ, et al. LPA3-mediated lysophosphatidic acid signalling in implantation and embryo spacing. Nature. 2005;435:104-108.

5. Mueller P, Ye S, Morris A, Smyth SS. Lysophospholipid mediators in the vasculature. Exp Cell Res. 2015;333:190-194.

6. Sordelli MS, Beltrame JS, Cella M, et al. Interaction between lysophosphatidic acid, prostaglandins and the endocannabinoid system during the window of implantation in the rat uterus. PLoS ONE. 2012;7:e46059.

7. Sordelli MS, Beltrame JS, Zotta E, et al. Endogenous lysophosphatidic acid participates in vascularization and decidualization at 
the maternal-fetal interface in the rat. Reprod Fertil Dev. 2017; https://doi.org/10.1071/ RD16235

8. Chen SU, Lee H, Chang DY, et al. Lysophosphatidic acid mediates interleukin-8 expression in human endometrial stromal cells through its receptor and nuclear factor-kappaB-dependent pathway: a possible role in angiogenesis of endometrium and placenta. Endocrinology. 2008;149:5888-5896.

9. Chen SU, Chou CH, Chao KH, et al. Lysophosphatidic acid upregulates expression of growth-regulated oncogene-alpha, interleukin-8, and monocyte chemoattractant protein-1 in human firstTrimester trophoblasts: possible roles in angiogenesis and immune regulation. Endocrinology. 2010;151:369-379.

10. Matsumoto H, Ma WG, Daikoku T, et al. Cyclooxygenase-2 differentially directs uterine angiogenesis during implantation in mice. J Biol Chem. 2002;277:29260-29267.

11. Sookvanichsilp N, Pulbutr P. Anti-implantation effects of indomethacin and celecoxib in rats. Contraception. 2002;65:373-378.

12. Lim H, Paria BC, Das SK, et al. Multiple female reproductive failures in cyclooxygenase 2-deficient mice. Cell. 1997;91: 197-208.

13. Sordelli MS, Beltrame JS, Burdet J, et al. The effect of anandamide on uterine nitric oxide synthase activity depends on the presence of the blastocyst. PLOS ONE. 2011;6:e18368.

14. Ota H, Igarashi S, Oyama N, Suzuki Y, Tanaka T. Optimal levels of nitric oxide are crucial for implantation in mice. Reprod Fertil Dev. 1999;11:183-188.

15. Purcell TL, Given R, Chwalisz K, Garfield RE. Nitric oxide synthase distribution during implantation in the mouse. Mol Hum Reprod. 1999;5:467-475.

16. Beltrame JS, Sordelli MS, Cella M, Perez Martinez S, Franchi AM, Ribeiro ML. Lysophosphatidic acid increases the production of pivotal mediators of decidualization and vascularization in the rat uterus. Placenta. 2013;34:751-756.

17. Graham CH, Hawley TS, Hawley RG, et al. Establishment and characterization of first trimester human trophoblast cells with extended lifespan. Exp Cell Res. 1993;206:204-211.

18. Irving JA, Lysiak JJ, Graham CH, Hearn S, Han VK, Lala PK. Characteristics of trophoblast cells migrating from first trimester chorionic villus explants and propagated in culture. Placenta. 1995; 16:413-433.

19. Armant DR, Kilburn BA, Petkova A, et al. Human trophoblast survival at low oxygen concentrations requires metalloproteinasemediated shedding of heparin-binding EGF-like growth factor. Development. 2006;133:751-759.

20. Kilburn BA, Wang J, Duniec-Dmuchowski ZM, Leach RE, Romero R, Armant DR. Extracellular matrix composition and hypoxia regulate the expression of HLAG and integrins in a human trophoblast cell line. Biol Reprod. 2000;62:739-747.

21. Kalkunte S, Lai Z, Tewari N, et al. In vitro and in vivo evidence for lack of endovascular remodeling by third trimester trophoblasts. Placenta 2008;29:871-878.

22. Arnaoutova I, George J, Kleinman HK, Benton G. The endothelial cell tube formation assay on basement membrane turns 20: state of the science and the art. Angiogenesis. 2009;12:267-274.

23. Scotti L, Di Pietro M, Pascuali N, et al. Sphingosine-1-phosphate restores endothelial barrier integrity in ovarian hyperstimulation syndrome. Mol Hum Reprod. 2016;22:852-866.

24. Español AJ, Maddaleno MO, Lombardi MG, Cella M, Martínez Pulido P, Sales ME. Treatment with LPS plus INF- $\gamma$ induces the expression and function of muscarinic acetylcholine receptors, modulating NIH3T3 cell proliferation: participation of NOS and COX. Br J Pharmacol. 2014;171:5154-5167.

25. Bradford M. A rapid and sensitive method for the quantitation of microgram quantities of protein utilizing the principle of proteindye binding. Anal Biochem. 1976;72:248-254.

26. Cella M, Farina MG, Dominguez Rubio AP, Di Girolamo G, Ribeiro ML, Franchi AM. Dual effect of nitric oxide on uterine prostaglandin synthesis in a murine model of preterm labour. $\mathrm{Br} \mathrm{J}$ Pharmacol. 2010;161:844-855.

27. de Luca Brunori I, Battini L, Brunori E, et al. Placental barrier breakage in preeclampsia: ultrastructural evidence. Eur J Obstet Gynecol Reprod Biol. 2005;118:182-189.

28. Wang Y, Lewis DF, Gu Y, Zhang Y, Alexander JS, Granger DN. Placental trophoblast-derived factors diminish endothelial barrier function. J Clin Endocrinol Metab. 2004;89:2421-2428.

29. Fraser R, Whitley G, Thilaganathan B, Cartwright JE. Decidual natural killer cells regulate vessel stability: implications for impaired spiral artery remodeling. J Reprod Immunol. 2015; 110:54-60.

30. Hu Y, Eastabrook G, Tan R, MacCalman CD, Dutz JP, von Dadelszen P. Decidual NK cell-derived conditioned medium enhances capillary tube and network organization in an extravillous cytotrophoblast cell line. Placenta. 2010;31:213-221.

31. Basak S, Duttaroy AK. Effects of fatty acids on angiogenic activity in the placental extravillious trophoblast cells. Prostaglandins Leukot Essent Fatty Acids. 2013;88:155-162.

32. Das MK, Basak S, Ahmed MS, Attramadal H, Duttaroy AK. Connective tissue growth factor induces tube formation and IL-8 production in first trimester human placental trophoblast cells. Eur J Obstet Gynecol Reprod Biol. 2014;181:183-188.

33. Alfaidy N, Chauvet S, Donadio-Andrei S, et al. Prion protein expression and functional importance in developmental angiogenesis: role in oxidative stress and copper homeostasis. Antioxid Redox Signal. 2013;18:400-411.

34. Li Y, Zhu H, Klausen C, Peng B, Leung PC. Vascular endothelial growth factor-a (VEGF-A) mediates activin a-induced human trophoblast endotheliallike tube formation. Endocrinology. 2015;156:4257-4268.

35. Highet AR, Buckberry S, Mayne BT, et al. First trimester trophoblasts forming endothelial-like tubes in vitro emulate a "blood vessel development" gene expression profile. Gene Expr Patterns. 2016;21:103-110.

36. Iwasawa Y, Fujii T, Nagamatsu T, et al. Expression of autotaxin, an ectoenzyme that produces lysophosphatidic acid, in human placenta. Am J Reprod Immunol. 2009;62:90-95.

37. Tokumura A, Kanaya Y, Miyake M, Yamano S, Irahara M, Fukuzawa K. Increased production of bioactive lysophosphatidic acid by serum lysophospholipase D in human pregnancy. Biol Reprod. 2002a;67:1386-1392.

38. Tokumura A, Majima E, Kariya Y, et al. Identification of human plasma lysophospholipase D, a lysophosphatidic acid-producing enzyme, as autotaxin, a multifunctional phosphodiesterase. J Biol Chem. 2002b;277:39436-39442.

39. Contos JJ, Fukushima N, Weiner JA, Kaushal D, Chun J. Requirement for the lpA1 lysophosphatidic acid receptor gene in normal suckling behavior. Proc Natl Acad Sci USA. 2000;97:13384-13389.

40. Contos JJ, Ishii I, Fukushima N, et al. Characterization of lpa(2) $(\mathrm{Edg} 4)$ and $\operatorname{lpa}(1) / \operatorname{lpa}(2)$ (Edg2/Edg4) lysophosphatidic acid 
receptor knockout mice: signaling deficits without obvious phenotypic abnormality attributable to $1 \mathrm{pa}(2)$. Mol Cell Biol. 2002;22:6921-6929.

41. Achache H, Tsafrir A, Prus D, Reich R, Revel A. Defective endometrial prostaglandin synthesis identified in patients with repeated implantation failure undergoing in vitro fertilization. Fertil Steril. 2010;94:1271-1278.

42. Parfenova H, Parfenov VN, Shlopov BV, et al. Dynamics of nuclear localization sites for COX-2 in vascular endothelial cells. Am J Physiol Cell Physiol. 2001;281:C166-C178.

43. Hamilton GS, Kennedy TG. Uterine vascular changes after unilateral intrauterine infusion of indomethacin and prostaglandin E2 to rats sensitized for the decidual cell reaction. Biol Reprod. 1994;50:757-764.

44. Stocco CO, Deis RP. Participation of intraluteal progesterone and prostaglandin F2 alpha in LH-induced luteolysis in pregnant rat. J Endocrino. 1998;156:253-259.

45. Callegari EA, Ferguson-Gottschall S, Gibori G. PGF2a induced differential expression of genes involved in turnover of extracellular matrix in rat decidual cells. Reprod Biol Endocrinol. 2005;3:3-13.

46. Al-Hijji J, Andolf E, Laurini R, Batra S. Nitric oxide synthase activity in human trophoblast, term placenta and pregnant myometrium. Reprod Biol Endocrinol. 2003;28:1-51.

47. Myatt L, Eis AL, Brockman DE, Kossenjans W, Greer I, Lyall F. Inducible (type II) nitric oxide synthase in human placental villous tissue of normotensive, pre-eclamptic and intrauterine growthrestricted pregnancies. Placenta. 1997;18:261-268.

48. Thomson AJ, Telfer JF, Kohnen G, et al. Nitric oxide synthase activity and localization do not change in uterus and placenta during human parturition. Hum Reprod. 1997;12:2546-2552.
49. Smith-Jackson K, Hentschke MR, Poli-de-Figueiredo CE, et al. Placental expression of eNOS, iNOS and the major protein components of caveolae in women with pre-eclampsia. Placenta. 2015;36:607-610.

50. Cartwright JE, Holden DP, Whitley GJ. Hepatocyte growth factor regulates human trophoblast motility and invasion: a role for nitric oxide. Br J Pharmacol. 1999;128:181-189.

51. Dunk C, Shams M, Nijjar S, et al. Angiopoietin-1 and angiopoietin2 activate trophoblast Tie-2 to promote growth and migration during placental development. Am J Pathol. 2000;156:2185-2199.

52. Xu B, Charlton F, Makris A, Hennessy A. Nitric oxide (NO) reversed TNF-alfa inhibition of trophoblast interaction with endothelial cellular networks. Placenta. 2014;35:417-421.

\section{SUPPORTING INFORMATION}

Additional Supporting Information may be found online in the supporting information tab for this article.

How to cite this article: Beltrame JS, Sordelli MS, Cañumil VA, Franchi AM, Ribeiro ML.

Lysophosphatidic acid-triggered pathways promote the acquisition of trophoblast endovascular phenotype in vitro. J Cell Biochem. 2017;1-15. https://doi.org/10.1002/jcb.26239 